\title{
Combining Ability Analysis for Bread Wheat (Triticum Aestivum L.)
}

\author{
Habtamu Seboka ${ }^{*}$, Amsalu Ayana ${ }^{2}$ and Habtamu Zelleke ${ }^{3}$ \\ ${ }^{1}$ Haramaya University , P O Box 48, Haramaya, Ethiopia \\ ${ }^{2}$ Oromia Agricultural Research Institute, P O Box 81265, Addis Ababa \\ ${ }^{3}$ Haramaya University, P O Box 147, Haramaya, Ethiopia
}

\begin{abstract}
Choice of promising genotypes from a diverse genetic base and subsequent utilization for hybridization is one of the strategies for improving productivity of bread wheat. The data from eight parents and their $F_{1}$ progenies of half-diallel crosses were analyzed for combining ability for yield and yield related traits in triplicate randomized complete block design in 2005 at Sinana, south-east Ethiopia. Significant differences among all the genotypes were apparent for all traits, except for biomass per plant. Both GCA and SCA mean squares revealed significant differences in plant height, harvest index, grain yield per plant, 1000-kernel weight and maturity traits, indicating the important of both additive and non-additive gene actions in the inheritance of these traits with the predominant effect of non-additive gene action. For the remaining traits, only mean square due to GCA showed significant variation, indicating the greater importance of additive gene action in controlling the inheritance of these characters. Abola gave highly significant GCA effects in the desirable direction and was the best general combiner for most of the traits, followed by Galema and Sofumer, while Dashen was the only parent which showed significant positive GCA effect for grain yield per plant. Cross combinations of Dashen x Galema, Abola x Dure, Dashen x Meda-Welabu, Abola x Galema, and Galema x Dure, exhibited significant SCA effects in the desired direction for at least two and, at most, for four traits, for which SCA variance showed significant differences. Hence, these crosses revealed possibility for commercial exploitation of heterosis as well as selection of potential homozygous lines from transgressive segregants for improvement of yield levels of bread wheat.
\end{abstract}

Keywords: Combining Ability; Diallel Cross; GCA; SCA; Triticum aestivum

\section{Introduction}

Bread wheat (Triticum aestivum L.) is a member of the tribe Triticeae of the family Poaceae to which all the major cereals belong. It is an autogamous allo-hexaploid species $(2 \mathrm{n}=6 \mathrm{x}=42)$ and three genomes, designated as A, B and $\mathrm{D}(\mathrm{AABBDD})$, were involved in its evolution (Morris and Sears, 1967). It combines the genomes of three diploid ancestrals, Triticum urartu $(2 \mathrm{n}=14$, AA), Aegilops squarrosa $(2 \mathrm{n}=14, \mathrm{DD})$ and Aegilops species $(2 \mathrm{n}=14$, $\mathrm{BB})$. Bread wheat has been cultivated for more than 10,000 years (Poehlman and Sleeper, 1995) and it is the world's leading food crop due to the viscoelastic properties of its endosperm gluten proteins.

Ethiopia is the largest producer of wheat in sub-Saharan Africa. The country ranks first in area coverage and second in production (FAO, 2005). An estimated area of 1.4 million hectare is under wheat production (CSA, 2005). The area under bread wheat has significantly increased from almost nil to $60 \%$ of the national wheat area (Amsal et al., 1995; Payne et al., 1996). This is because of its higher productivity, broader adaptation and use of semi-dwarf, input responsive high yielding improved varieties.

Despite the significant increases in area of wheat production in the country, the mean national wheat yield is $1.5 \mathrm{t} / \mathrm{ha}$ (CSA, 2005). This relatively low productivity may be partially attributed to the prevalence of virulent crop pathogens, lack of a durable resistant variety, soil nutrient depletion and grass weeds in major wheat producing areas. To this effect, the choice of promising genotypes from a diverse genetic base and their subsequent utilization for hybridization is one of the strategies for improving productivity of bread wheat. Therefore, advanced materials from international and national wheat improvement programs have been immediate sources of bread wheat varieties for release or for use as parental stocks (Amsal et al., 1996; Getachew et al., 1997).

Further advancement in the yield of bread wheat requires adequate information regarding the nature of combining ability of the parents to be used in the hybridization program and also the nature of gene actions involved in the expression of quantitative and qualitative traits of economic importance. Combining ability analysis developed by Griffing (1956) has been widely used to derive information about the ability of parents to transfer their desirable traits to their progenies and compare the performance of lines in hybrid combinations. It also helps to identify the best hybrid combinations and supplies data on the type of gene action, which is a key to selecting an appropriate breeding procedure in any breeding program (Cukandor-Olmedo et al., 1997; Nazir et al., 2005). The general combining ability (GCA) and specific combining ability (SCA) effects are very effective genetic parameters in deciding the next phase of the breeding program. It appears that the GCA rank for grain yield is related to the GCA for the useful yield components and it is, therefore, recommended that the breeder should breed for superior combining ability for the component traits with an ultimate objective of improving the overall GCA for grain yield in bread wheat (Joshi et al., 2004).

In this study, therefore, an effort was made to generate information about eight released cultivars of bread wheat crossed in half-diallel fashion so as to identify the best combining parents and their crosses on the basis of their general and specific combining abilities effects for yield and yield related traits for further improvement of grain yield in bread wheat. In addition, this study also 
determined the type of gene actions involved in the inheritance of yield and its components.

\section{Materials and Methods}

Combining ability analysis for yield and yield related traits in bread wheat (Triticum aestivum L.) using $8 \times 8$ half-diallel cross was conducted at Sinana Agricultural Research Center (SARC), on-station, during the main cropping season of 2005. The center is characterized by bimodal rainfall and, hence, wheat is produced twice a year. Rainfall data for the last 16 years (1990-2005) showed that average total annual rainfall was $752 \mathrm{~mm}$ which ranged from 535 to $1018 \mathrm{~mm}$. The main season receives 230 to $546 \mathrm{~mm}$ (average $353 \mathrm{~mm}$ ) rainfall, in which the lowest level was observed in 2005 main cropping season, and the short season receives from 225 to $560 \mathrm{~mm}$ (average 364 $\mathrm{mm})$. For the same period, the average annual maximum temperature was $21.2{ }^{\circ} \mathrm{C}$ and minimum temperature was $9.4{ }^{\circ} \mathrm{C}$. The dominant soil type is pellic Vertisol and is slightly acidic $(\mathrm{pH}=6)$.

The experimental materials consisted of a total of 36 genotypes, which comprised the parents and $28 \mathrm{~F}_{1}$ 's obtained from $8 \times 8$ half-diallel crossing of genetically diverse bread wheat cultivars selected based on their individual merits. The parents basically originated from CIMMYT/Ethiopia and were released as high yielding and adapted varieties by the agricultural research system during the period $1984-2001$ (Table 1). These parents have genetic variability for yield, disease resistance as well as for various yield components. Crossing was done at $\mathrm{SARC}$ in 2004 in both seasons on field and in greenhouse to obtain sufficient amount of $F_{1}$ seeds.

Table 1. Passport data and characteristics of bread wheat varieties included in $8 \times 8$ half-diallel cross.

\begin{tabular}{|c|c|c|c|c|}
\hline Parent & $\begin{array}{l}\text { Origin/So } \\
\text { urce }\end{array}$ & Pedigree & $\begin{array}{l}\text { Year of } \\
\text { release }\end{array}$ & Attributes \\
\hline $\begin{array}{l}\text { Wabe } \\
\text { (HAR-710) }\end{array}$ & $\begin{array}{l}\text { CIMMYT/ } \\
\text { Ethiopia }\end{array}$ & MRL 'S" - BUC 'S' & 1995 & $\begin{array}{l}\text { High yielder, long spike, } \\
\text { susceptible to yellow and stem } \\
\text { rusts, and semi-dwarf, White } \\
\text { seeded }\end{array}$ \\
\hline $\begin{array}{l}\text { Mitike } \\
\text { (HAR 1709) }\end{array}$ & $\begin{array}{l}\text { CIMMYT/ } \\
\text { Ethiopia }\end{array}$ & BOW 28 / RBC & 1994 & $\begin{array}{l}\text { Susceptible to yellow rust, } \\
\text { moderately high yielder, tall, } \\
\text { resistant to stem rust, and good } \\
\text { competitive to weed }\end{array}$ \\
\hline Dashen & $\begin{array}{l}\text { CIMMYT/ } \\
\text { Ethiopia }\end{array}$ & $\begin{array}{l}\text { VEE17, KUZ- BUHO "S"x KAL - } \\
\text { BB CM33027-F-15M-500y-1M-OY- } \\
\text { OPtz-OY }\end{array}$ & 1984 & $\begin{array}{l}\text { Good baking quality, white } \\
\text { seeded, high tillering capacity, } \\
\text { susceptible to yellow and stem rust, } \\
\text { and high yielder }\end{array}$ \\
\hline $\begin{array}{l}\text { Sofumer } \\
\text { (HAR 1889) }\end{array}$ & $\begin{array}{l}\text { CIMMYT/ } \\
\text { Ethiopia }\end{array}$ & LIRA'S'/YAN'S' & 1999/00 & $\begin{array}{l}\text { High yielder, susceptible to } \\
\text { moderately, susceptible to yellow } \\
\text { and stem rusts, frost tolerant, high } \\
\text { tillering capacity, white seeded, and } \\
\text { short spike }\end{array}$ \\
\hline $\begin{array}{l}\text { Abola } \\
\text { (HAR 1522) }\end{array}$ & $\begin{array}{l}\text { CIMMYT/ } \\
\text { Ethiopia }\end{array}$ & BOW'S'/BUC'S' & 1997 & $\begin{array}{l}\text { High yielder, susceptible to yellow } \\
\text { and stem rusts, and very long } \\
\text { spike and White seeded }\end{array}$ \\
\hline $\begin{array}{l}\text { Galema } \\
\text { (HAR-604) }\end{array}$ & $\begin{array}{l}\text { CIMMYT/ } \\
\text { Ethiopia }\end{array}$ & 4777(2)//FKN/GB/3/ PVN "S" & 1995 & $\begin{array}{l}\text { High yielder, late maturing, high } \\
\text { tillering capacity, and moderately } \\
\text { resistance to yellow and stem rusts }\end{array}$ \\
\hline $\begin{array}{l}\text { Meda-Welabu } \\
\text { (HAR-1480) }\end{array}$ & $\begin{array}{l}\text { CIMMYT/ } \\
\text { Ethiopia }\end{array}$ & $\begin{array}{l}\text { TL/3/FR/Th/Nar59*2/4/BOL'S'C } \\
\text { M56569-/AP-1AP-5AP-2AP-OAP }\end{array}$ & $1999 / 00$ & $\begin{array}{l}\text { High yielder, has good resistance to } \\
\text { yellow, susceptible to stem rust, } \\
\text { long spike, Plump seed }\end{array}$ \\
\hline $\begin{array}{l}\text { Dure } \\
\text { (HAR 1008) }\end{array}$ & $\begin{array}{l}\text { CIMMYT/ } \\
\text { Ethiopia }\end{array}$ & $\begin{array}{l}\text { BOW"S"/YD"s"/ZZ'S" } \\
\text { CM62045-1Y-1M-1Y-1M-6Y-1M-OY }\end{array}$ & 2001 & $\begin{array}{l}\text { Moderately High yielder, early } \\
\text { maturing, white seeded and good } \\
\text { for moisture stress area }\end{array}$ \\
\hline
\end{tabular}

The resulting seeds of 36 genotypes (28 $\mathrm{F}_{1}$ 's and 8 parents) were sown in a triplicate randomized complete block design (RCBD) at SARC, on station in August 24, 2005. Planting was done manually by dibbling two seeds per hill, which were later thinned to one plant. Each plot consisted of four rows of $1.5 \mathrm{~m}$ length and spacing of 20 $\mathrm{cm}$ between rows and $15 \mathrm{~cm}$ between plants.
Recommended doses of $41-46 \mathrm{~kg} \mathrm{~N}-\mathrm{P}_{2} \mathrm{O}_{5} /$ ha fertilizer were applied at planting and hand-weeding was done three times. The systemic fungicide, Propiconazole (Tilt) was sprayed at a rate of $0.5 \mathrm{l} / \mathrm{ha}(125 \mathrm{~g}$ a.i $/ \mathrm{ha})$ at booting and heading to control yellow and stem rusts, respectively. 
Five plants, randomly taken from two central rows of each plot, were used for recording observations for characters considered on a sample basis: plant height, spike length, flag leaf area, tillers/plant, seeds/spike, seeds/spikelet, spikelets/spike, seeds weight/spike, grain yield/plant, biomass/plant and harvest index. On the other hand, two central rows were used for recording observations for characters considered on a plot basis: days to heading, days to maturity, days to grain filling and thousand kernel weight.

Analysis of variance (ANOVA) was carried out following the procedures outlined by Steel and Torrie (1980) to determine the presence of significant differences among the genotypes using SAS computer program. Griffing's (1956) model I (fixed effect model) method 2 combining ability analysis was employed to estimate GCA and SCA for characters that showed significant differences among the genotypes using SPAR-1 statistical software (Doshi and Gupta, 1991).

Test of significance for GCA and SCA mean squares was made using the F-test. The significance of GCA and SCA effects was tested by comparing with tabular ' $\mathrm{t}$ ' values of 1.96 and 2.58 multiplied by standard errors in which they were associated $\left(1.96 \times \mathrm{SE}\left(\mathrm{g}_{\mathrm{i}}\right)\right.$ and $2.58 \times \mathrm{SE}$ $\left.\left(\mathrm{s}_{\mathrm{ij}}\right)\right)$ at $5 \%$ and $1 \%$ probability levels, respectively. The estimated values of $g_{i}$ and $s_{i j}$ greater than $1.96 \times \mathrm{SE}\left(\mathrm{g}_{\mathrm{i}}\right)$ and $1.96 \times \mathrm{SE}\left(\mathrm{s}_{\mathrm{ij}}\right)$ for GCA and SCA effects were regarded as significant at $5 \%$ probability level and the estimated values greater than $2.58 \times \mathrm{SE}\left(\mathrm{g}_{\mathrm{i}}\right)$ and $2.58 \times \mathrm{SE}$ $\left(\mathrm{s}_{\mathrm{ij}}\right)$ were regarded as significant at $1 \%$ probability level (Dabholkar, 1992). Taking the expectation mean squares for model I Method 2 into consideration, the estimated component of genetic variance due to GCA of parents and SCA of the hybrids were computed. The predominance of additive versus non-additive gene action in the expression of the character was compared from the ratio of components of GCA variance $\left(\sigma^{2} \mathrm{GCA}\right)$ to SCA variance $\left(\sigma^{2} \mathrm{SCA}\right)$.

\section{Results and Discussion}

The analysis of variance revealed highly significant $(\mathrm{P}<0.01)$ differences among the 36 genotypes for all traits studied, except biomass yield per plant (Table 2), indicating the presence of inherent variation among the materials. Further partitioning of the sum of squares due to genotypes into that of parents, crosses and parents vs. crosses indicated that mean square due to parents was highly significant $(\mathrm{P}<0.01)$ and significant $(\mathrm{P}<0.05)$ for all traits except seed weight per spike, grain yield and biomass per plant. Hybrids also showed highly significant and significant differences for all traits except days to maturity and seed weight per spike. Highly significant difference was recorded for parent vs. hybrids in flag leaf, plant height, days to heading, days to grain filling, days to maturity, seed weight per spike, grain yield per plant, harvest index and 1000-kernel weight, indicating the presence of directional dominance which resulted in heterosis for these traits. Similarly, several previous studies reported significant differences among genotypes for grain yield and yield related traits in different sets of material of wheat (Menon and Sharma, 1997; Ali and Khan, 1998; Javaid et al., 2001; Solomon, 2002). Therefore, it was justifiable to estimate GCA and SCA effects for those traits which showed significant differences for genotypes.

Table 2. Mean squares due to genotypes, parents, crosses, and parent vs. crosses for 15 yield and yield related traits from the analysis of variance (ANOVA) in $8 \times 8$ half-diallel cross of bread wheat in 2005 at Sinana, south east, Ethiopia.

\begin{tabular}{|c|c|c|c|c|c|c|c|}
\hline & Mean Square & & & & & & \\
\hline & Replications & Genotypes & Parents & Hybrids & Parents vs. Hybrids & Error & $\mathrm{CV}$ \\
\hline Trait & $\mathrm{df} \quad(2)$ & (35) & (7) & $(27)$ & $(1)$ & $(70)$ & $(\%)$ \\
\hline $\mathrm{DH}$ & 15.45 & $74.38^{* *}$ & $147.42 * *$ & $35.86^{* *}$ & $603.19 * *$ & 5.62 & 2.99 \\
\hline DGF & 18.78 & 51.19 ** & 121.21 ** & $29.43^{* *}$ & $148.60^{* *}$ & 7.55 & 2.05 \\
\hline $\mathrm{DM}$ & 32.62 & $17.77 * *$ & $17.19 *$ & 12.91 & $153.02^{* *}$ & 8.18 & 1.98 \\
\hline PH & 15.94 & $48.92^{* *}$ & $52.89 * *$ & $47.77 * *$ & $52.30 *$ & 11.22 & 3.48 \\
\hline ТРP & 50.77 & $19.90^{*}$ & $23.79 *$ & $19.17 *$ & 12.60 & 11.09 & 19.88 \\
\hline FLA & 59.92 & $62.02 * *$ & $105.83^{* *}$ & $45.70^{* *}$ & $195.80 * *$ & 12.73 & 7.48 \\
\hline SL & 3.26 & $1.09 * *$ & $2.76 * *$ & $0.69 *$ & 0.12 & 0.39 & 5.09 \\
\hline SPS & 302.12 & $149.53 * *$ & $445.71 * *$ & $77.70^{* *}$ & 15.89 & 38.16 & 8.06 \\
\hline SPPS & 0.69 & $1.85^{* *}$ & $3.71 * *$ & $1.44^{*}$ & 0.01 & 0.72 & 3.79 \\
\hline SPSP & 1.15 & $0.34 * *$ & $0.57 * *$ & $0.28^{*}$ & 0.35 & 0.16 & 11.99 \\
\hline SWS & 0.17 & $0.28^{* *}$ & 0.24 & 0.20 & $2.69^{* *}$ & 0.14 & 11.21 \\
\hline GYP & 268.11 & $138.20^{* *}$ & 30.17 & $142.67 *$ & $773.57 * *$ & 71.58 & 20.26 \\
\hline BMP & 2020.93 & 595.57 & 303.16 & $654.87 *$ & 1041.35 & 379.5 & 19.54 \\
\hline $\mathrm{HI}$ & 5.20 & $28.07 * *$ & $27.71^{* *}$ & $21.54^{* *}$ & $206.82^{* *}$ & 8.92 & 7.18 \\
\hline TKW & 6.06 & $35.82 * *$ & $42.72 * *$ & $23.24 * *$ & $327.23^{* *}$ & 5.73 & 5.76 \\
\hline Note: & ignificant at & 0.01 level & obability, & vely, $d f$ & e of freedom. & & \\
\hline $\begin{array}{l}D H=I \\
\text { blant, } F \\
\text { SPPS = } \\
\text { (g). HI }\end{array}$ & $\begin{array}{l}\text { beading, } D C \\
\text { Flag leaf are } \\
\text { ber of spikele }\end{array}$ & Days to gr & $\begin{array}{l}\text { illing, } D \\
\text { length }\end{array}$ & ays to & $\begin{array}{l}\text { PH = Plant heig } \\
\text { of seeds per spike, }\end{array}$ & mber & $\begin{array}{l}\text { fillers } p \\
\text { or spikel } \\
\text { s per pla }\end{array}$ \\
\hline
\end{tabular}




\subsection{Combining Ability Analysis}

Analysis of variance for combining ability revealed that both GCA and SCA mean squares were highly significant $(\mathrm{P}<0.01)$ for plant height, days to heading, days to grain filling, days to maturity, harvest index, 1000-kernel weight and significant $(\mathrm{P}<0.05)$ for grain yield per plant (Table 3 ), suggesting the importance of both additive and nonadditive gene actions in determining the inheritance of these characters. The Results of this study are in accordance with the findings of Necdet (2001) and Joshi et al. (2004), who reported highly significant difference for both GCA and SCA for these traits. However, further variance ratio analysis showed that non-additive gene action has primary importance for the inheritance of these traits except days to grain filling (Table 3). The present findings thus supported the results of Menon and Sharma (1997), who reported non-additive genetic variance as the main component of genetic variance of these traits. However, preponderance of additive gene effects were reported by Joshi et al. (2004), Javaid et al. (2001) and Nazir et al. (2005) for these traits, except 1000kernel weight, which was predominantly controlled by non-additive gene action.
The mean squares for general combining ability were highly significant $(\mathrm{P}<0.01)$ and significant $(\mathrm{P}<0.05)$ for all the remaining traits, flag leaf area, tillers per plant, spike length, seed per spike, spikelets per spike, seed per spikelet and seed weight per spike, indicating the greater importance of additive gene action in controlling the inheritance of these characters, since SCA mean squares were non-significant for these traits. As indicated by various authors (Gravois and McNew, 1993; Joshi et al., 2004), when GCA is only important, especially in selfpollinated crops, selection is the best method of breeding to improve the character in question. This is because additive effects are readily transmissible from one generation to another. In addition, Habib and Khan (2003), Joshi et al. (2004) and Nazir et al. (2005) also reported the greater importance of additive gene effect in controlling the expression of these traits. Contrary to these observations, Ali and Khan (1998)) reported the importance of both additive and non-additive gene action for flag leaf area, tillers per plant and seeds per spike. Arshad and Chowdhry (2002) detected the predominant effect of non-additive variances in flag leaf area, tillers per plant, seeds per spike and grain yield per plant.

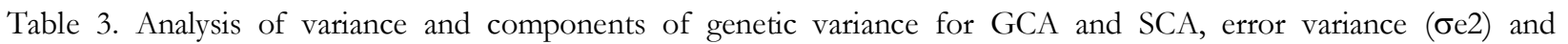
$\sigma 2 \mathrm{gca} / \sigma 2 \mathrm{sca}$ ratio for yield and yield related traits in 8 × 8 half-diallel cross of bread wheat in 2005 at Sinana, south east, Ethiopia.

\begin{tabular}{llllllll}
\hline Trait & Mean squares & \multicolumn{5}{c}{ Variance component } \\
\cline { 2 - 8 } & GCADF $(7)$ & $\operatorname{SCA}(27)$ & Error(70) & $\sigma_{\text {gca }}^{2}$ & $\sigma^{2}$ sca & $\sigma_{\mathrm{e}}^{2}$ & $\sigma^{2}$ gca $/ \sigma^{2}{ }_{\text {sca }}$ ratio \\
\hline DH & $77.62^{* *}$ & $11.59^{* *}$ & 1.88 & 7.57 & 9.71 & 1.88 & 0.78 \\
DGF & $60.81^{* *}$ & $6.13^{* *}$ & 2.52 & 5.83 & 3.61 & 2.52 & 1.62 \\
DM & $7.25^{*}$ & $5.59^{* *}$ & 2.73 & 0.45 & 2.86 & 2.73 & 0.16 \\
PH & $44.75^{* *}$ & $9.20^{* *}$ & 3.74 & 4.10 & 5.46 & 3.74 & 0.75 \\
TPP & $23.06^{* *}$ & 2.53 & 3.70 & 1.94 & 1.16 & 3.70 & - \\
FLA & $80.63^{* *}$ & 5.68 & 4.24 & 7.64 & 1.44 & 4.24 & - \\
SL & $1.37^{* *}$ & 0.11 & 0.13 & 0.12 & 0.02 & 0.13 & - \\
SPS & $205.42^{* *}$ & 10.95 & 12.72 & 19.27 & 1.77 & 12.72 & - \\
SPPS & $2.42^{* *}$ & 0.17 & 0.24 & 0.22 & 0.07 & 0.24 & - \\
SPSP & $0.40^{* *}$ & 0.04 & 0.05 & 0.03 & 0.009 & 0.05 & - \\
SWS & $0.19^{* *}$ & 0.07 & 0.04 & 0.01 & 0.02 & 0.05 & - \\
GYP & $75.05^{* *}$ & $38.82^{*}$ & 23.86 & 5.12 & 14.95 & 23.86 & 0.34 \\
HI & $12.29^{* *}$ & $8.62^{* *}$ & 2.97 & 0.93 & 5.65 & 2.97 & 0.16 \\
TKW & $22.23^{* *}$ & $9.37^{* *}$ & 1.91 & 2.03 & 7.46 & 1.91 & 0.27 \\
\hline
\end{tabular}

Note:-*, **, Significant at 0.05 and 0.01 level of probability, respectively, $d f=$ degree of freedom.

$D H=$ Days to heading, DGF $=$ Days to grain filling, DM = Days to maturity, $P H=$ Plant height (cm), TPP $=$ Number of tillers per plant, FL $A=$ Flag leaf area $\left(\mathrm{cm}^{2}\right), S L=$ Spike length $(\mathrm{cm}), S P S=$ Number of seeds per spike, SPPS= Number of spikelet per spike, SPSP $=$ Number of seeds per spikelet, SWS = Seed weight per spike (g), GYP = Grain yield per plant (g), HI = Harvest index (\%), $T K W=1000$ kernel weight $(g)$.

\subsubsection{Estimates of General Combining Ability Effects}

Based on the results from analysis of variance for combining ability, the GCA effects of parents for yield and its component characters were estimated (Table 4). For grain yield, three parents revealed significant GCA effects, out of which Dashen gave desirable significant positive GCA effect and was the best general combiner for this trait. Sofumer, Meda-Welabu, and Galema also recorded positive GCA effect and were equally important for use in parental combination for grain yield. Dure and Mitike showed negative and significant GCA effect and were the poorest general combiners for grain yield in this study. Therefore, from this study, Dashen, Sofumer and Meda-Welabu could be utilized in bread wheat grain yield improvement programs as a selection from these crosses which could be expected to lead to substantial genetic improvement. In this study, it is also interesting to 
observe that there was concurrence between per se performance and GCA effects for grain yield per plant. This study is in agreement with Arshad and Chowdhry (2002) and Joshi et al. (2004), who reported greater and positive GCA effects in most of the crosses for grain yield. They also reported those parents with higher GCA effects resulting in higher SCA effects for grain yield.

All parents, except Wabe, showed highly significant $(\mathrm{P}<0.01)$ and significant $(\mathrm{P}<0.05)$ GCA effect, out of which three parents were in the desirable positive direction for 1000-Kernel weight. Dure, Sofumer and Meda-Welabu were the best general combiners, while Abola was the poorest general combiner for this trait followed by Dashen and Mitike. In this study, even though Dure was the best general combiner for 1000kernel weight, it exhibited highly significant negative GCA effects for all spike traits, which may be attributed to negative GCA effect for grain yield.

For spike length, all parents, except Mitike, showed highly significant $(\mathrm{P}<0.01)$ GCA effects, out of which Dure, Dashen and Sofumer had undesirable negative GCA effect and were poor general combiners for this character. Galema and Meda-Welabu followed by Abola and Wabe were good general combiners for spike length. The results of this study are in conformity with the findings of Arshad and Chowdhry (2002), Topal et al. (2004) and Nazir et al. (2005), who reported both positive and negative GCA effects for 1000-kernel weight and spike length.

All of the parents, except Wabe and Meda-Welabu exhibited significant GCA effect for number of tillers per plant, out of which Dure, Abola, and Mitike had unfavorable negative GCA effects for this trait. Dashen, Galema and Sofumer exhibited significant positive GCA effect and so were good general combiners for this trait. For flag leaf area, Wabe, Abola, Galema and MedaWelabu revealed positive and highly significant GCA effects. All these parents were equally good general combiners, while Mitike, Sofumer and Dure recorded negative and highly significant GCA effects and were poor general combiner for this trait. Arshad and Chowdhry (2002) and Nazir et al. (2005) reported similar results for tillers per plant and flag leaf area, respectively.

Two parents, Dashen and Abola, had negative and highly significant GCA effect, while Mitike and Galema showed highly significant positive GCA effects for plant height. Thus, the former two parents were the best general combiners for dwarfness, while the latter two were poor general combiners. One half of the parents showed negative GCA effect out of which $25 \%$ showed significant GCA effect in the negative desirable direction for plant height in bread wheat improvement. This result is in accordance with Arshad and Chowdhry (2002), Javaid et al. (2001) and Nazir et al. (2005), who reported significant negative GCA effects in most of the crosses and strong positive association of dwarfness with grain yield.

In the present study, six of the 8 parents, showed highly significant GCA effects, out of which Dure and Mitike had negative GCA effects in the desirable direction for days to heading. While, Galema, Abola, Sofumer and Dashen showed highly significant positive GCA effects in an undesirable direction. Dure was the best general combiner for early heading and maturity; Galema and Abola were the poorest general combiners for respective traits. There was a close agreement between parental lines selected on the per se performance and their GCA effects for these traits. This was also true with respect to the poor general combiners parental genotypes for these particular traits in this study. Similarly, Joshi et al. (2004) and Javaid et al. (2001) reported considerable amount of negative GCA effects for days to heading and maturity.

The results of this study revealed significant GCA effects for number of seeds per spike and spikelets per spike in four parents, out of which only Abola had positive and highly significant GCA effects for the former and Abola and Sofumer for the latter trait. Similarly, significant GCA effects were recorded in five and two parents for number of seeds per spikelet and seed weight per spike, respectively, out of which Abola and Galema had positive and highly significant GCA effects for the former and only Abola for the latter trait. Therefore, it was observed that Abola was the best general combiner for number of seeds per spike, spikelets per spike, and seeds per spikelet and seed weight per spike. Moreover, Sofumer and Galema were also best general combiners for number of spikelets per spike and seeds per spikelet, respectively. However, Dure, Sofumer and Wabe exhibited significant negative GCA effects and were poor general combiners for seeds per spike; Dure and Wabe were poor general combiners for number of spikelets per spike; Dure, Sofumer and Mitike were poor general combiners for seeds per spikelet and Mitike was the poorest general combiner for seed weight per spike.

Generally, Abola was the best general combiner for all spike traits (number of seeds per spike, seeds per spikelet and seed weight per spike), while Dure followed by Wabe and Mitike showed negative GCA effects for all these traits and were poor general combiners for respective traits. These results revealed a close agreement between per se performance and GCA effect for these characters and hence, selection from the transgressive segregating generations of crosses of Abola could be expected to lead to substantial genetic improvement for these traits. Contrary this results, Javaid et al. (2001), Arshad and Chowdhry 2002) and Nazir et al. (2005) reported positive GCA effects in most of the crosses for these traits. 
Table 4. Estimates of general combining ability effect for 14 yield and related quantitative traits of eight parental genotypes of bread wheat in 2005 at Sinana, south east, Ethiopia.

\begin{tabular}{|c|c|c|c|c|c|c|c|c|c|c|}
\hline \multirow[b]{2}{*}{ Trait } & \multicolumn{8}{|l|}{ Parent } & \multirow[t]{2}{*}{$\mathrm{SE}(\mathrm{d}) g i_{ \pm}$} & \multirow[t]{2}{*}{$\mathrm{SE}(\mathrm{d}) g i-g \dot{j}_{ \pm}$} \\
\hline & Wabe & Mitike & Dashen & Sofumer & Abola & Galema & Dure & Meda-Welabu & & \\
\hline$\overline{\mathrm{DH}}$ & 0.63 & $-1.74 * *$ & $1.13^{* *}$ & $1.79 * *$ & $1.63^{* *}$ & $3.09 * *$ & $-5.81 * *$ & -0.71 & 0.41 & 0.61 \\
\hline DGF & -0.18 & $2.12^{* *}$ & $-1.88^{* *}$ & $-2.15^{* *}$ & -0.25 & $-3.08^{* *}$ & $4.38 * *$ & 1.05 & 0.47 & 0.71 \\
\hline DM & 0.44 & 0.38 & -0.76 & -0.36 & $1.38^{* *}$ & 0.01 & $-1.43^{* *}$ & 0.34 & 0.49 & 0.74 \\
\hline $\mathrm{PH}$ & -0.98 & $3.55^{* *}$ & $-2.51 * *$ & 0.46 & $-2.59 * *$ & $1.81^{* *}$ & 0.93 & -0.68 & 0.57 & 0.86 \\
\hline TPP & -0.07 & $-1.17 *$ & $2.10^{* *}$ & $1.30^{*}$ & $-1.33^{*}$ & $1.70^{*}$ & $-1.90 * *$ & -0.63 & 0.57 & 0.86 \\
\hline FLA & $2.42^{* *}$ & $-3.47 * *$ & -0.36 & $-2.92^{* *}$ & $2.65^{* *}$ & $3.18^{* *}$ & $-3.15^{* *}$ & $1.66^{* *}$ & 0.61 & 0.92 \\
\hline SL & $0.26^{* *}$ & -0.02 & $-0.32 * *$ & $-0.29 * *$ & $0.22^{* *}$ & $0.39 * *$ & $-0.61 * *$ & $0.37^{* *}$ & 0.11 & 0.16 \\
\hline SPS & $-2.29 *$ & -1.83 & -1.03 & $-3.59 *$ & $10.04 * *$ & 2.01 & $-3.99 *$ & 0.68 & 1.05 & 1.59 \\
\hline SPPS & $-0.34^{*}$ & -0.06 & -0.04 & $0.39 * *$ & $0.93^{* *}$ & -0.01 & $-0.74 * *$ & -0.12 & 0.15 & 0.22 \\
\hline SPSP & -0.05 & $-0.15^{*}$ & -0.12 & $-0.15^{*}$ & $0.38^{* *}$ & $0.22^{* *}$ & $-0.15^{*}$ & 0.02 & 0.07 & 0.10 \\
\hline SWS & -0.08 & $-0.13^{* *}$ & -0.09 & -0.08 & $0.27^{* *}$ & 0.06 & -0.06 & 0.11 & 0.06 & 0.10 \\
\hline GYP & -2.71 & $-3.12^{*}$ & $3.56^{*}$ & 2.10 & 0.40 & 1.35 & $-3.54 *$ & 2.00 & 1.44 & 2.18 \\
\hline $\mathrm{HI}$ & $-2.08^{*}$ & -0.83 & 0.34 & $1.17^{*}$ & 0.82 & -0.69 & 0.36 & 0.90 & 0.51 & 0.77 \\
\hline TKW & -0.19 & $-1.29 * *$ & $-1.06^{*}$ & $1.31 *$ & $-1.46 * *$ & $-0.99 *$ & $2.61^{* *}$ & $1.07 * *$ & 0.41 & 0.62 \\
\hline
\end{tabular}

Note: - * **, Significant at 0.05 and 0.01 level of probability, respectiveb

$D H=$ Days to heading, DGF $=$ Days to grain filling, DM = Days to maturity, $P H=$ Plant height (cm), TPP $=$ Number of tillers per plant, FL $A=$ Flag leaf area $\left(\mathrm{cm}^{2}\right), S L=$ Spike length $(\mathrm{cm}), S P S=$ Number of seeds per spike, SPPS= Number of spikelets per spike, $S P S P=$ Number of seeds per spikelet, SWS = Seed weight per spike (g), GYP = Grain yield per plant (g), HI = Harvest index (\%), $T K W=1000$ kernel weight $(g)$.

\subsubsection{Estimates of Specific Combining Ability Effects}

In this study, crosses manifested considerable variation in SCA effects for a few traits (Table 5). For grain yield per plant, six of the 28 crosses manifested significant SCA effect. The maximum significant SCA effect was recorded in Dashen $x$ Meda-Welabu followed by Sofumer $\mathrm{x}$ Galema and Sofumer x Meda-Welabu, whereas the lowest (negative) and significant SCA effect was obtained from Dure $\mathrm{x}$ Meda-Welabu. This indicated that Dashen $\mathrm{x}$ Meda-Welabu, Sofumer x Galema and Sofumer x MedaWelabu crosses combined well to give higher grain yield than mean performances of their respective parents. Based on this result, these crosses could be selected for their specific combining ability and useful for transgressive breeding for grain yield improvement. In this study, good SCA for grain yield was observed in a few crosses. However, Arshad and Chowdhry (2002) and Hussian et al. (2004) reported significance of SCA effects in a considerable number of crosses and indicated the predominance of non-additive genetic variance in the case of grain yield.

For 1000-kernel weight, seven of the 28 crosses manifested highly significant SCA effect, out of which only one cross, Wabe x Sofumer, showed a negative and significant SCA effect. The maximum SCA effect was recorded in Dashen x Meda-Welabu cross followed by Abola x Meda-Welabu and Sofumer x Dure, whereas the lowest (negative) SCA effects were obtained from Wabe $\mathrm{x}$ Sofumer. This indicated that Dashen x Meda-Welabu, Abola x Meda-Welabu and Sofumer x Dure crosses combined well to give higher 1000-kernel weight mean performances than their respective parents and could be selected for their specific combining ability to improve 1000-kernel weight. Moreover, it was observed that actual 1000-kernel weight recorded for these crosses (per se performance) was superior to other crosses. Thus, there was close agreement between crosses selected on the basis of their SCA effects and per se performance for 1000-kernel weight and grain yield in this study.

In this study, most of the crosses identified as desirable, on the basis of their SCA effects for these traits, had at least one of the parents involved as a good general combiner for the trait. Hence selection from the transgressive segregating generations of these crosses is most probably lead to substantial genetic improvement for 1000-kernel weight and grain yield in bread wheat. This study is in agreement with Topal et al. (2004) and Nazir et al. (2005), who reported greater positive SCA effects in most of the crosses for 1000-kernel weight. Arshad and Chowdhry (2002) and Joshi et al. (2004) also reported that crosses involving one of the parents with high GCA effect also resulted in high SCA effect for most of the traits they studied. Contrary to the present study, Necdet (2001) reported negative and significant SCA effects in most of the crosses for 1000-kernel weight. For harvest index, seven crosses manifested significant SCA effect in desirable positive direction, while Dure x Meda-Welabu and Wabe x Dure showed significant SCA effect in a negative direction. For this trait, Abola x Dure and Wabe x Galema were the best specific combiners.

Similarly, seven crosses exhibited significant SCA effects for plant height out of which three crosses combined well in the desirable direction in reducing plant height. The best specific combiners for plant height were Dashen x Galema followed by Wabe x Dashen which had a shorter plant height than the mean value of the parent involved in each crosses, while Sofumer x Dure was the poorest combiner for this trait. This study also revealed that there was close agreement between crosses selected on the basis of their SCA effects and per se performance 
Habtamu et al.

for dwarfness. This was also true with respect to the poor specific combiner as well. Similarly, considerable negative and significant SCA effects for plant height and its importance for wheat improvement were reported by Topal et al. (2004), Arshad and Chowdhry (2002) and Javaid et al. (2001).

For maturity traits, eight and five crosses revealed highly significant and significant SCA effects for days to heading and maturity, respectively. None of the crosses showed significant negative SCA for days to grain filling in this study, indicating that hybrids were later in grain filling than what would have been predicted based on their parental performances.

Significant positive SCA effects were recorded in Sofumer x Galema for heading, Abola x Galema and Mitike $x$ Meda-Welabu for grain filling and Mitike $x$ Meda-Welabu and Dure x Meda-Welabu for maturity which were also poor specific combiners for respective traits. Those crosses that recorded maximum negative SCA effect such as, Abola x Galema and Wabe x Sofumer
Combining Ability Analysis for in Bread Wheat

for heading and Abola x Dure and Wabe x Dure for maturity were good specific combiners for respective traits and may be used as good sources for earliness. Even though only one cross showed significant SCA effect, most of the crosses involving Dure as a parent exhibited negative SCA effect for these maturity traits. This result revealed that a good specific combiner for days to heading may not necessarily be a good specific combiner for grain filling.

It was also observed that some crosses involving parents with good general combiners showed poor specific combiners, indicating parents with high GCA effect might not always give crosses with high SCA effects. In this study, negative direction was considered as a desirable SCA effect for traits like days to heading, grain filling, maturity and plant height. Similarly, Topal et al. (2004) and Javaid et al. (2001) reported negative and significant SCA effects for days to heading and maturity.

Table 5 Estimates of specific combing ability effects for yield and some yield related traits of 28 hybrids in 8 x 8 halfdiallel cross of bread wheat in 2005 at Sinana, south east, Ethiopia.

\begin{tabular}{|c|c|c|c|c|c|c|c|}
\hline Cross & $\mathrm{DH}$ & DGF & $\mathrm{DM}$ & $\mathrm{PH}$ & GYP & $\mathrm{HI}$ & TKW \\
\hline $\mathrm{P}_{1} \times \mathrm{P}_{2}$ & -2.00 & 2.12 & 0.19 & 1.48 & -1.08 & $2.86^{*}$ & 0.65 \\
\hline $\mathrm{P}_{1} \times \mathrm{P}_{3}$ & -1.20 & 0.46 & -0.75 & $-4.26 * *$ & -4.29 & 0.39 & -1.99 \\
\hline $\mathrm{P}_{1} \times \mathrm{P}_{4}$ & $-3.87 * *$ & 1.72 & -2.15 & 0.58 & -5.26 & -0.07 & $-2.68^{*}$ \\
\hline $\mathrm{P}_{1} \times \mathrm{P}_{5}$ & $-2.70^{*}$ & 0.49 & -2.22 & -0.85 & 0.04 & -1.06 & -2.12 \\
\hline $\mathrm{P}_{1} \times \mathrm{P}_{6}$ & -1.84 & 0.32 & -1.52 & -0.77 & 2.62 & $4.09 * *$ & 0.68 \\
\hline $\mathrm{P}_{1} \times \mathrm{P}_{7}$ & -0.60 & -2.14 & $-2.75^{*}$ & 0.18 & 3.21 & $-2.69 *$ & -0.45 \\
\hline $\mathrm{P}_{1} \times \mathrm{P}_{8}$ & 0.96 & -1.81 & -0.85 & 2.31 & 4.47 & $2.90^{*}$ & 1.35 \\
\hline $\mathrm{P}_{2} \times \mathrm{P}_{3}$ & -1.84 & -0.84 & $-2.68^{*}$ & -2.98 & -1.59 & -2.47 & -1.22 \\
\hline $\mathrm{P}_{2} \times \mathrm{P}_{4}$ & $-2.84 * *$ & 0.76 & -2.08 & 1.06 & -1.06 & 1.28 & 0.15 \\
\hline $\mathrm{P}_{2} \times \mathrm{P}_{5}$ & -0.67 & 1.86 & 1.19 & -1.90 & -0.06 & -1.25 & 0.39 \\
\hline $\mathrm{P}_{2} \times \mathrm{P}_{6}$ & -1.47 & 0.36 & -1.12 & 2.18 & -2.67 & 0.60 & 0.31 \\
\hline $\mathrm{P}_{2} \times \mathrm{P}_{7}$ & -0.24 & -1.11 & -1.35 & 0.26 & 1.31 & 1.29 & 1.92 \\
\hline $\mathrm{P}_{2} \times \mathrm{P}_{8}$ & -1.00 & $3.89 * *$ & $2.89 *$ & 2.79 & $7.71 *$ & -0.93 & 1.52 \\
\hline $\mathrm{P}_{3} \times \mathrm{P}_{4}$ & -0.04 & 1.42 & 1.38 & $-3.22 *$ & -1.00 & -0.36 & -0.75 \\
\hline $\mathrm{P}_{3} \times \mathrm{P}_{5}$ & 0.13 & 0.86 & 0.99 & 2.56 & 5.83 & 0.95 & 1.95 \\
\hline $\mathrm{P}_{3} \times \mathrm{P}_{6}$ & $-3.34 * *$ & 1.36 & -1.98 & $-4.57 * *$ & -1.95 & $3.00 *$ & $2.95^{* *}$ \\
\hline $\mathrm{P}_{3} \times \mathrm{P}_{7}$ & -0.44 & -0.78 & -1.22 & $3.92 *$ & 6.73 & 1.02 & 1.49 \\
\hline $\mathrm{P}_{3} \times \mathrm{P}_{8}$ & 0.13 & -0.78 & -0.65 & -1.49 & $13.69 * *$ & $3.07 *$ & $4.75^{* *}$ \\
\hline$P_{4} \times P_{5}$ & -1.20 & 0.12 & -1.08 & -2.07 & -1.70 & 0.53 & -0.08 \\
\hline $\mathrm{P}_{4} \times \mathrm{P}_{6}$ & $2.99 * *$ & -0.71 & 2.29 & 1.07 & $9.11 *$ & 2.17 & 1.85 \\
\hline $\mathrm{P}_{4} \times \mathrm{P}_{7}$ & 0.23 & -0.84 & -0.62 & $4.42^{* *}$ & -1.00 & -0.64 & $3.86^{* *}$ \\
\hline $\mathrm{P}_{4 \times} \mathrm{P}_{8}$ & $-3.20 * *$ & 0.82 & -2.38 & 1.08 & $8.13^{*}$ & -0.89 & 1.46 \\
\hline $\mathrm{P}_{5} \times \mathrm{P}_{6}$ & $-6.50 * *$ & $6.72 * *$ & 0.22 & $3.98^{*}$ & $7.91 *$ & -182 & $3.02 * *$ \\
\hline $\mathrm{P}_{5} \times \mathrm{P}_{7}$ & $-2.94 * *$ & -1.08 & $-4.02^{* *}$ & $3.73^{*}$ & -0.53 & $7.87 * *$ & 0.23 \\
\hline $\mathrm{P}_{5} \times \mathrm{P}_{8}$ & -2.04 & 0.59 & -1.45 & -0.87 & 2.66 & 2.22 & $4.56^{* *}$ \\
\hline $\mathrm{P}_{6} \times \mathrm{P}_{7}$ & -1.07 & 1.09 & 0.02 & -0.60 & 3.22 & $2.82^{*}$ & $2.89 * *$ \\
\hline $\mathrm{P}_{6} \times \mathrm{P}_{8}$ & -0.17 & 1.09 & 0.92 & 1.27 & -4.89 & -0.73 & 0.02 \\
\hline $\mathrm{P}_{7} \times \mathrm{P}_{8}$ & 1.40 & 1.62 & $3.02^{*}$ & 1.15 & $-9.47 *$ & $-3.48^{* *}$ & -0.64 \\
\hline $\mathrm{SE}(\mathrm{d}) \mathrm{Sij}_{ \pm}$ & 1.08 & 1.25 & 1.30 & 1.53 & 3.85 & 1.36 & 1.09 \\
\hline SE(d)Sij-Sik & 1.84 & 2.13 & 2.22 & 2.59 & 6.55 & 2.31 & 1.85 \\
\hline $\mathrm{SE}(\mathrm{d}) \mathrm{Sij}-\mathrm{Skl}$ & 1.73 & 2.01 & 2.09 & 2.45 & 6.17 & 2.18 & 1.75 \\
\hline
\end{tabular}

Note: - *, **, significant at 0.05 and 0.01 probability Level, respectively, SE. = Standard error

$D H=$ Days to heading, $D G F=$ Days to grain filling, $D M=$ Days to maturity, $P H=$ Plant height $(\mathrm{cm}), H I=$ Harvest index $(\%)$,

$T K W=1000$ kernel weight $(g)$. 


\section{Conclusions}

The presence of both additive and non-additive variances suggested the utilization of certain genotypes and crosses for future breeding work. Therefore, use of diallel mating with recurrent selection and integration with pedigree selection could be suggested as a breeding program to exploit both additive and non-additive gene effects for the genetic improvement of bread wheat. Thus, parental genotypes with good GCA like Abola, Dashen, Sofumer, Meda-Welabu and Galema and specific crosses scored highly. SCA like Dashen x Galema, Abola x Dure, Dashen x Meda-Welabu, Abola x Galema, and Galema x Dure, should be included in multiple crosses for tangible improvement of grain yield in bread wheat.

\section{References}

Ali, Z. and Khan, A.S.1998. Combining ability studies of some morpho-physiological traits in bread wheat (Triticum aestivum L.). Pakistan Journal of Agricultural Science 35:1-3.

Amsal, T., Getnet, G., Tanner, D. G. and Bekele, G.1996. Trends in beard wheat yield improvement in Ethiopia from the 1967 to 1994. In: Tanner, D. G., Payne, T.S. and Abdalla, O. s. (eds.). The Ninth Regional Wheat Workshop for Eastern, Central and southern Africa. Addis Ababa, Ethiopia: CIMMY'T. pp. 333-337.

Amsal, T., Tanner, D.G. and Getnet, G. 1995. Implementation in yield of bread wheat cultivars released in Ethiopia from 1947 to 1987. Africa Crop Science Journal 3: 41-49.

Arshad, M. and Chowdhry, M. A. 2002. Impact of environment on the combining ability of bread wheat genotypes. Pakistan Journal of Biological Science 5: 13161320.

Bell, G.D.H. 1987. The History of Wheat Cultivation. In: Lupton, F.G.H.(eds.). Wheat Breeding. Chapman and Hall, London. pp. 31-49.

Cukandor-Olmedo, B., Miller, J.F. and Hammond, J.J. 1997. Combining ability of the stay green trait and seed moisture content in sun flower. Crop Science 37: 378-382.

CSA (Central Statistical Authority). 2005. Agricultural sample survey 2004/05. Report on area and production for major meher season crops for private peasant holdings. Statistical bulletin (1) 311, Addis Ababa, Ethiopia.

Dabholkar, A.R.1992. Elements of Biometrical Genetics. Concept Publishing Company, NewDelhi 110059.

Doshi, S.P. and Gupta, K.C. 1991. SPAR (Statistical Package for Agricultural Research). ICAR, New Delhi.

FAO (Food and Agricultural Organization). 2005. Production Year Book. Rome, Italy.

Gavian, S., and Gemechew, D. 1996. The profitability of wheat production in Ethiopia: The case of Tiyo Woreda in Arsi Region. Ethiopian Journal of Agricultural Economics 1:38-62.

Getachew, B. 1997. Genetic Variation, breeding potential and cytogenetics profile of Ethiopian tetraploid wheat (triticum turgidum L.) Land races. PhD dissertation. Swedish University of Agricultural Sciences. Uppsala, Sweden.

Gravois, K.A. and McNew, R.W. 1993. Combining ability and heterosis in U.S. southern long rice grain. Crop Science 33: 90-95.

Griffing, B. 1956. Concept of general and specific combining ability in relation to diallel crossing systems. Australian Journal of Biological Science 9:463493.

Habib, I. and Khan, A. S. 2003. Genetic model of some economic traits in bread wheat (Triticum aestivum L.). Asian Journal of Plant Science 2: 1153 - 1155.

Hussian, F., Ashraf, M., Mehdi, S.S. and Ahmad, M.T. 2004. Estimation of heterosis for grain yield and its related traits in bread wheat (Triticum astivum L.) under leaf rust conditions. Journal of Biological Science 4: 637-644.

Javaid, A., Massod, S. and Minhas, N.M. 2001. Analysis of combining ability in wheat (Triticum aestivum L.) using $\mathrm{F}_{2}$ generation. Pakistan Journal of Biological Science 4:1303-1305.

Joshi, S. K., Sharma, S. N., Singhania, D. L. and Sain, R. S. 2004. Combining ability in $F_{1}$ and $F_{2}$ generations of diallel cross in hexapliod wheat (Triticum aestivum L.). Heredity 141:115-121.

Menon, U. and Sharma, S. N. 1997. Genetics of yield determining factors in spring wheat over environments. Indian Journal of Genetics 57: 301 -306.

Morris, R. and Sears, E. R. 1967. The cytogenetics of wheat and its relatives. In: Quisenberry, K.S. and Reitz, L.P. (eds.). Wheat and Wheat improvement. Madison, WI, USA, American Society of Agronomy. pp. 19-87.

Nazir, S., Khan, A. and Ali, Z. 2005. Combining ability analysis for yield and yield contributing traits in bread wheat. Journal of Agricultural Soc. Science 1: 129-132.

Necdet, D. 2001. heterosis and Combining ability in an 8 x 8 Diallel Durum wheat population. Ege Üniversitesi, Ziraat Fakültesi Dergisi 38: 55-62.

Payne, S. T., Tanner, D.G. and Abdalla, O.S. 1996. Current issues in wheat research and production in eastern, central and south Africa: Changes and Challenges. In: Tanner, D.G., Payne, T.S. and Abdalla, O.S. (eds.). The ninth regional wheat workshop for eastern, central and southern Africa. Addis Ababa, Ethiopia: CIMMY'T. pp. 1-27.

Poehlman, J. M. and Sleeper, D. A. 1995. Breeding Field Crops. $4^{\text {th }}$ edition. ANI, INC. Westport, Connecticut.

Solomon, G. 2002. Genetic analysis in bread wheat (Triticum aestivum L.) for yield, yield attributing traits and disease resistance. M.Sc. Thesis, University of Agricultural Sciences, Dharwad-5, India.178p.

Steel, R. G. D. and Torrie, J. H. 1980. Principles and Procedures of Statistics. A Biological Approach. McGraw Hill Book Co., New York.

Topal, A., Aydin, C., Akgun, N. and Babaoglu, M. 2004. Diallel crosses analysis in durum wheat (Triticum durum Desf.): identification of best parents for some kernel physical features. Field Crops Research 87: 1- 12. 